\title{
A CONFIGURAÇÃO ONTOLÓGICO-ÉTICA DA ECONOMIA
}

\author{
THE ONTOLOGICAL AND ETHICAL CONFIGURATION OF THE ECONOMY
}

Manfredo Araújo de Oliveira*

\begin{abstract}
RESUMO
A economia é uma dimensão do ser humano, consequentemente, considerá-la filosoficamente pressupõe uma concepção determinada do ser humano que, enquanto ser material/biológico, efetiva-se economicamente constituindo um sistema de relações de produção, repartição e consumo num contexto social. Para o projeto atual do capitalismo não podemos julgar boas ou más as leis da natureza, do mesmo modo não podemos julgar as leis do mercado: elas se impõem a nós. O mercado não pertence ao campo das interações humanas, é algo incontrolável, não tem, portanto, sentido aqui levantar questões éticas. Este artigo procura mostrar, no horizonte de outra concepção do ser humano, que o que está em jogo na ética é a conquista do ser humano enquanto ser livre. Isso significa a configuração de sua vida histórica enquanto construção da relação com a natureza e das relações com outros humanos. A exigência fundamental da ética é o respeito a todo ser, o que exige a superação de toda ordem social radicada na exploração e na injustiça social e ecológica.
\end{abstract}

PALAVRAS-CHAVE: Economia. Liberdade. Ética. Justiça.

\section{ABSTRACT}

The economy is a dimension of the human being. Therefore, considering it philosophically presupposes a human being determined conception, as material/biological being which carries itself out economically, constituting a system of relations of productions, partition, and consume in a social context. To the actual project of capitalism, we might not judge nature laws as good or bad ones, like we might not judge the market laws: they impose themselves on us. The market does not belong to the field of human interactions; it is something uncontrollable. However, there is no purpose to raise ethical issues. This paper seeks to demonstrate, on the horizon of another conception of human being, that what it is at stake in ethics is the conquest of the human being as a free being. That means the configuration of his historical life as a construction of the relation between nature and his peers. The fundamental ethic demand is respect to every being, which requires an overcoming of every social order rooted in the exploration and in social and ecological injustice.

KEYWORDS: Economy. Freedom. Ethic. Justice.

\footnotetext{
* Professor titular da Universidade Federal do Ceará. E-mail: manfredo.oliveira@uol.com.br.
} 
A economia é uma dimensão do ser humano, portanto, tratar filosoficamente da economia pressupõe sempre uma "ideia determinada" do ser humano, uma antropologia fundamental. Trata-se, na tematização dessa "ideia de ser humano", em primeiro lugar da explicitação e reconstrução sistemática das "dimensões básicas" que expressam o que compete necessariamente ao ser humano enquanto ser humano, ou seja, aquelas características que ele não poderia deixar de ter sem deixar de ser o que é. Tematizando-se a “constituição própria do ser humano", tematiza-se consequentemente o lugar que ele ocupa no universo. Tal empreendimento é uma reconstrução crítica do já conhecido nos contextos quotidianos de vida e nas ciências, orientada com o objetivo de captar os constitutivos essenciais do ser humano ${ }^{1}$.

\section{TRAÇOS FUNDAMENTAIS DO SER HUMANO}

A filosofia, aqui pressuposta, parte da tese fundamental de que a linguagem é a instância de expressabilidade de toda e qualquer realidade, ou seja, a linguagem é constitutivamente linguagem de algo, assim, linguagem do mundo, e o mundo é mundo enquanto expressável na linguagem, portanto, instância de sua expressabilidade, o que é o pressuposto de qualquer empreendimento teórico. É justamente nesse sentido que se afirma que a semântica, a teoria da dimensão significativa da linguagem, é uma "semântica realista" já que suas sentenças articulam um relacionamento ao real. Por essa razão se parte das sentenças teóricas que exprimem algo, uma proposição: ela exprime algo do mundo.

Na tradição, este algo foi compreendido como "substância" que é uma categoria dual: só se pode falar dela em vinculação com as determinações que predicamos a ela, seus atributos, isto é, "propriedades e relações". Se removemos todas essas determinações, permanece somente uma entidade inteiramente indeterminada, portanto ininteligível, o que a torna inaceitável por uma teoria filosófica. Ora, como todas as outras entidades do mundo, o ser humano foi também pensado como uma substância com suas propriedades e relações. Daí o desafio central neste contexto: articular uma compreensão do ser humano sem pressupor uma “ontologia da substância” (PUNTEL, 2008, p. 276 et seq.; OLIVEIRA, 2014, p. 236 et seq.).

\footnotetext{
${ }^{1}$ A respeito das diferentes propostas de compreensão do ser humano no debate contemporâneo, veja Viana (2019).
} 
Uma proposição, quando verdadeira, é idêntica a uma entidade do mundo, a um fato do mundo, um "fato primo" que é a única categoria ontológica admitida em nível fundamental nesta filosofia o que significa que se trata, no sentido estrito, de uma ontologia monocategorial. Fato primo é, então, qualquer entidade que é um elemento do mundo, da realidade, e desta forma se deve dizer que o mundo é a totalidade dos fatos primos. Fatos primos complexos constituem uma "configuração", o substituto da substância da ontologia tradicional. Assim, as coisas do mundo, os indivíduos, sobretudo os indivíduos humanos, são configurações de fatos primos que podem ser dos mais diferentes tipos. A questão central que se põe agora nesse contexto é como deve ser pensada a configuração que constitui o indivíduo humano, quais são seus elementos constitutivos.

Trata-se, então, aqui, de tematizar e reconstruir de forma sistemática as estruturas fundamentais que expressam as determinações constitutivas do ser humano, ou seja, sua constituição ontológica específica. Trata-se de articular um quadro conceitual que expresse o que necessariamente ${ }^{3}$ compete ao ser humano enquanto ser humano, ou seja, aqueles elementos que o ser humano não poderia deixar de ter para poder ser o que é enquanto ser humano, sua configuração própria, sua constituição ontológica e consequentemente o lugar que corresponde a essa configuração no todo.

Puntel (2008, p. 363-364) faz nesse contexto uma distinção esclarecedora para o enfrentamento dessa problemática. Ele distingue entre os constituintes absolutamente necessários do ser humano que são seus constituintes "essenciais", aqueles que competem ao ser humano "simpliciter", isto é, independentemente de qualquer situação geográfica, histórica, etc., como o intelecto, a vontade e a consciência/autoconsciência. Os constituintes "relativa ou historicamente essenciais", que nunca podem faltar, mas que são dados exclusivamente com uma concretização como, por exemplo, ter um corpo que sempre pressupõe um determinado lugar, um determinado tempo, etc. e, por fim, os constituintes "contingentes" que surgem historicamente e podem desaparecer historicamente, como, por exemplo, morar numa determinada rua.

\footnotetext{
${ }^{2}$ Primo é a expressão utilizada para indicar que aqui é afastada a categoria de substância.

${ }^{3}$ Cf. Planting (1974), Kripke (1980, 2001). Esse é o assim chamado problema do essencialismo que não pode ser enfrentado sem considerações modais. Distinguem-se dois tipos de propriedades dos objetos: as essenciais e as acidentais. Assim, "P é uma propriedade essencial a $\mathbf{x}$ se, e somente se, $\mathbf{x}$ exemplifica $\mathbf{P}$ em todos os mundos possíveis em que $\mathbf{x}$ existe” (BRANQUINHO, 2002, p. 157).
} 
a) A corporalidade enquanto dimensão básica

Em primeiro lugar, o ser humano se manifesta como uma realidade material-orgânica e, enquanto tal, como "uma parte da natureza", uma parte do universo, já que é um "corpo orgânico", marcado, portanto, por uma determinada configuração corporal-biológica. Enquanto dimensão primeira, o corpo constitui o pressuposto da consciência, da autoconsciência e da intersubjetividade humanas. Assim, a corporalidade emerge como mediação irrecusável das relações dos seres humanos entre si e dos seres humanos com o mundo natural. O corpo, por ser uma dimensão constitutiva do propriamente humano, não pode simplesmente ser reduzido a um "objeto" entre outros no mundo dos objetos.

No entanto, o ser humano se pode pôr de alguma forma frente a seu corpo, objetivá-lo e configurá-lo. Portanto, o ser humano, em sentido estrito, é seu corpo e é enquanto tal que ele está no mundo como sujeito que pode intervir na natureza para transformá-la. Precisamente através de sua intervenção na natureza, ele pode experimentar tanto sua transcendência sobre ela como também sua dependência dela para a satisfação de suas necessidades naturais.

Enquanto ser corporal-orgânico, então, o ser humano faz parte do mundo objetivo, é, por conseguinte, portador das propriedades que constituem os entes materiais e dos entes biológicos (RICOEUR, 1991, p. 39 et seq.) ${ }^{4}$ como configuração teleonômica, metabolismo, reprodução, mortalidade, reações bioquímicas, posse de células, órgãos, capacidade de receber estímulos e trabalhá-los, percepções, impulsos, emoções, instintos, estar sujeito a leis físicas e químicas, fisiológicas e biológicas, vulnerável a influências externas, a acidentes e doenças, a violências e exploração, aflição por preocupações vitais, isto é, está marcado pela necessidade de ter que adquirir as condições materiais de sua existência; o ser humano é um fenômeno no mundo com outros seres de seu domínio e de outros domínios.

b) O ser humano enquanto ser inteligente: abertura à totalidade do ser

A pertença do ser humano ao campo do ser biológico é, contudo, de alguma forma paradoxal: por um lado, ele é portador de uma determinação biológica com todos os limites congênitos que isso implica; por outro, está de certo modo para além de qualquer limite, de qualquer determinação, pois transcende através da "pergunta" o imediato e se distancia de tudo o que ele encontra. Seus atos mostram a aptidão por ele possuída de se distanciar do

\footnotetext{
${ }^{4}$ Cf. também: Jonas (1973, 1992, p. 9-100); Strawson (1972, p. 133 et seq.).
} 
mundo e de si mesmo e de alargar com isso as possibilidades que lhe são abertas. Ele se mostra, assim, enquanto "ser da linguagem", como o lugar em que toda e qualquer realidade se exprime, diz-se. O ser humano é aquela instância em que se articula em princípio a compreensão de tudo, portanto portador de um "horizonte irrestrito". Essa capacidade manifesta algo especificamente humano, e desta forma se começa a esboçar seu lugar na totalidade do real e a grandeza específica de seu ser.

Isso implica uma consequência fundamental na determinação da constituição ontológica do ser subjetivo: enquanto coextensivo com o universo ele não pode ser reduzido a um elemento que é simplesmente meio para os outros elementos do universo. Porque coextensivo com o universo ele é, então, o "ponto de referência do universo" e, enquanto tal, não pode ser reduzido a puro meio. Ele é o ente que é fim em si mesmo num sentido estritamente ontológico. Para exprimir essa realidade a tradição empregou o conceito de "pessoa".

c) O ser humano enquanto autoconsciência e autoafirmação

O ser humano é em princípio capaz de alargar qualquer conhecimento de coisas, eventos, processos do mundo, efetivado através das categorias da linguagem, e ele faz isso na "consciência implícita" de que é ele mesmo, identidade na mudança desses atos de conhecimento, quem realiza essa expansão. Em qualquer forma de consciência do outro, de conhecimento dos entes do mundo, faz-se presente uma "consciência de si" implícita, atemática e não objetiva, isto é, pré-proposicional ${ }^{5}$. Assim, o ser humano sabe de si mesmo, conhece a si mesmo, no próprio ato de conhecer qualquer ente, não enquanto objeto desse conhecimento, mas enquanto seu sujeito a partir da perspectiva da primeira pessoa do singular, de um "eu" , retornado a si do mundo e de suas inúmeras ocorrências, voltado para si num saber e num afirmar-se originários de si mesmo, o que produz uma familiaridade

\footnotetext{
${ }^{5}$ Nagel (1981) distingue entre um "saber como" e um "saber que" para dizer que há fatos cuja verdade não é expressa através de proposições.

${ }^{6}$ Para Heintel (1984, p. 204), o ser humano só é ser humano porque pode dizer "Eu" e porque assim sabe de si mesmo como identidade na modificação de certezas, percepções e representações. Numa palavra, também o ser humano fático enquanto ser humano só existe na diferença transcendental e, portanto, não é simplesmente um objeto como outros no mundo objetivo.
} 
íntima e indubitável consigo mesmo $^{7}$ e manifesta a diferença de si mesmo em relação a qualquer outra realidade.

d) O ser humano enquanto ser de vontade: sua abertura ao bem

O ser humano não quer simplesmente ser, mas quer realizar sua forma própria de ser ser sujeito -, efetivar-se enquanto sujeito, e é nesse sentido que P. Ricoeur considera o sujeito antes de tudo como um movimento ${ }^{8}$. Assim, ele afirma sua identidade própria e enquanto tal se apreende como um ser de possibilidades interpelado a automediar-se, a configurar-se e a configurar seu mundo. Esta é a exigência básica de sua vida, portanto, o "sentido primeiro" da vida enquanto ação: a interpelação a ser em seu mundo, a expandir aí suas possibilidades, o que revela sua finitude constitutiva e o projeto fundamental de sentido na dimensão pragmática. Nesse sentido, pode-se dizer que o ser do ser humano não é uma realidade simplesmente constatável, algo já dado, mas antes uma tarefa. Isto é aquilo que se denomina de ação e que tem a ver com a vontade que, enquanto tal, é uma dimensão essencial do ser humano enquanto ser espiritual, uma de suas duas dimensões entrelaçadas e complementares, inteligência e vontade, as duas realizações da coextensividade intencional ao Ser em seu todo.

Tudo isso mostra que as ideias do "verdadeiro" (inteligência) e do "bom" (vontade) são as grandes descobertas do ser humano enquanto ser espiritual e são inelimináveis, pois mesmo aquele que julga toda verdade uma ilusão tem que considerar verdadeira sua convicção. Precisamente por essa razão, essas ideias abrem um horizonte de liberdade que vai muito além da liberdade entendida simplesmente enquanto liberdade negativa de coações internas ou externas. O verdadeiro e o bom abrem, para o ser humano, um espaço de libertação: ele pode sempre se perguntar pelas razões teóricas e práticas de suas crenças e, com isto, se libertar das causas cegas, que o impulsionam.

e) A pessoa humana enquanto livre, autodeterminada

Por ser intencionalmente coextensivo ao ser em seu todo e poder, então, distanciar-se de tudo, o ser humano emerge como entidade capaz em princípio de "pôr tudo em questão".

\footnotetext{
${ }^{7}$ Cf. Frank (1991, p. 5, 7, 9, 15). Por esta razão, para Frank é um absurdo perguntar se e como aquele que atribui um saber a respeito de si mesmo pode saber se é o mesmo que aquele a quem este saber se refere. Trata-se, portanto, de uma autorreferência infalível (p. 253 et seq.).

${ }^{8}$ Cf. Piva (1999, p. 206): "O sujeito corresponde a um movimento do si, pronome reflexivo de todos os pronomes gramaticais, pessoais e impessoais, que percorrendo seus atos, experiências e objetivações, é capaz de se retomar reflexivamente, de se apropriar de sua identidade".
} 
Isto lhe torna possível distanciar-se de tudo através da "reflexão crítica". Com isso, pode elevar-se acima de tudo numa reflexão radical sobre tudo, desligar-se, "descolar-se" de tudo, inclusive de si mesmo, de suas representações, motivações, seus impulsos, padrões de comportamento etc. Este alargamento constitui precisamente a potencialidade do que chamamos o "espírito humano", ou seja, "inteligência" e "vontade" em sentido estrito enquanto faculdades de referência ao mundo ilimitado, abrangente. Dessa forma, a coextensividade intencional do espírito humano com o Ser em seu todo é um constituinte fundamental do espírito humano que o revela como ser "desligado" e, neste sentido fundamental, "livre".

O ser humano, enquanto ser da linguagem, revelou-se como a instância que expressa a compreensão de qualquer realidade, e é através dela que se dá a ordenação e a classificação de tudo o que é experimentado através de uma rede de conceitos. Somente pela mediação desses quadros conceituais pode o ser humano reduzir a imensa complexidade do real por ele experimentado e, portanto, estruturar e organizar sua experiência de mundo. Na realidade, a respeito de todos os conceitos, emerge, inevitavelmente, a possibilidade da pergunta sobre sua legitimidade. Ora, justamente, aqui, se situa a grande façanha do ser humano: ele levanta $a$ questão da validade que se pode pôr tanto a respeito de nossas atividades de "compreensão" do mundo como das razões que pretendem legitimar nossas "ações" no mundo. Trata-se, então, de determinar as ações por motivos racionais (OLIVEIRA, 1995, p. 96 et seq.).

O ser humano é, em princípio, capaz de se distanciar de suas próprias ideias e de seus próprios desejos, pois pergunta se são elas "verdadeiras" e se eles são moralmente "corretos". Isso significa que o ser humano pode perguntar pelos "critérios" que devem orientar sua vida. Isso é o grande passo que ele dá além do mundo infra-humano. Por essa razão o ser humano delibera, avalia, julga e toma decisões, o que é incompatível com a tese do "determinismo" (INWAGEN, 2008, p. 329-330), que afirma que o passado e as leis da natureza juntos determinam a cada momento um futuro único, ou seja, nossas ações não são fruto de nossas decisões, nosso comportamento não depende de nós, o que significa que não temos responsabilidade sobre o que fazemos ${ }^{9}$, a liberdade é, então, uma ilusão. Num mundo entendido como um processo completo de determinação causal, tanto natural como política,

\footnotetext{
${ }^{9}$ A respeito da posição do determinismo, ver Viana (2016, p. 120): “[...] ninguém é livre para determinar o próprio comportamento. Para físicos deterministas, a pessoa não passa de um aglomerado físico-químico regulado pelas leis da natureza; para biólogos, o comportamento humano é fruto de determinações genéticas; para neurologistas fisicalistas, todo livre desejo não é mais do que o efeito de interações sinápticas”.
} 
portanto, como um sistema de necessidade, não tem sentido falar de liberdade (KRINGS, 1973, p. 495-496).

$\mathrm{Na}$ esfera do conhecimento, Kutschera (1998, p. 208) defende a tese contrária de que sem liberdade não pode haver conhecimento, pensamento, e inicia sua argumentação afirmando que o sujeito que conhece é decisivamente um agente livre que age com limites. Certamente, há no ser humano estados e operações que têm causas que manifestam nossa passividade como, por exemplo, as sensações. De modo geral pensar significa julgar, raciocinar, diferenciar, avaliar, formar uma opinião de tal maneira que se pode dizer: para os deterministas não há pensamento no sentido normal da palavra e não há sujeito. Se minha opinião já é de antemão determinada, não posso avaliar, não posso julgar, não posso tomar posição. Numa palavra, conhecer e julgar pressupõem liberdade.

$\mathrm{Na}$ esfera da vida prática isso tem como consequência poder passar de uma vida que busca os critérios de ação simplesmente em fatos sociais existentes - como, por exemplo, nas tradições, nas concepções de vida ou nos valores hegemônicos em sua situação histórica -, para uma reflexão avaliativa sobre os valores ou as normas que ele deve aceitar como condutores de sua vida. Isso implica responsabilidade pelas escolhas que fazemos. Kutschera aponta aqui para a distinção entre causas e motivos ou razões. Razões falam a respeito da correção de uma convicção, causas não fazem isso. Normas de racionalidade só têm sentido quando o destinatário pode agir de acordo com seu sentido ou contra esse sentido, isto é, quando ele se determina responsavelmente para sua ação. Por essa razão, para ele, liberdade é incompatível com determinismo: uma ação, assim, só pode ser dita livre quando ela poderia ter sido de outro modo (KUTSCHERA, 1998, p. 203, 208-210).

Assim, é a própria razão humana, e não uma simples decisão arbitrária, que deve responder à pergunta: que devo fazer? O que para nós constitui fatos em nossa vida não pode constituir uma resposta a essa pergunta, pois esses fatos mesmos podem ser objeto de questionamento sobre sua validade. Por essa razão é insuficiente aquele conceito de "liberdade", hoje muito difundido, que a interpreta como o poder realizar o que se quer, pois os desejos e os motivos que nos movem podem ser induzidos e manipulados socialmente. Quanto maior é a necessidade de satisfazer a eles menos livre é o ser humano, uma vez que, assim, se nega justamente aquilo que constitui a liberdade enquanto liberdade, ou seja, a "autonomia". Do ponto de vista psicológico, isto é, dos motivos que nos levam a agir, outros fundamentos diferentes dos racionais podem de fato ser os móveis de nossas ações. Por isso se faz necessária uma avaliação crítica. 
Pode-se dizer que toda a filosofia de Kant é movida por uma intenção subjacente: mostrar que a verdadeira grandeza do ser humano não consiste simplesmente, como pensa a modernidade, em sua capacidade de se impor sobre o mundo, de submeter a natureza a seus desejos, mas em "sua capacidade de autodeterminar-se a partir da liberdade". Não simplesmente a técnica, mas a liberdade - e com isso o ético -, é a fonte da grandeza do ser humano.

Espiritualidade significa, assim, distanciamento crítico, liberdade, transcendência: posso afastar tudo de mim enquanto nomeio, capto; tornar tudo objeto de consideração e de ação. Mas isso significa a possibilidade e consequentemente a responsabilidade na condução e configuração da própria existência numa palavra, o ser espiritual não é só inteligência, mas também vontade e autoconsciência, e é enquanto tal que ele é coextensivo à totalidade do real.

f) A liberdade é essencialmente construção de relações

A liberdade humana é um processo de passagem de nossa capacidade de distanciamento crítico frente a tudo para a configuração efetiva de nossas vidas históricas em que antes de tudo se mostra com clareza a distância e a tensão permanente entre a efetividade da situação e o que nela nos é disponível e o horizonte irrestrito que nos marca. "[...] o ser humano nunca é originariamente um sujeito puro sem mundo e sem história, ele não é nunca uma subjetividade fechada em si mesma, mas é constitutivamente aberto ao grande todo, ao universo enquanto tal... relação ao mundo e relação a si mesmo [...]" (OLIVEIRA, 2012, p. 247).

Por isso, nosso processo de construção e conquista do humano do ser humano ocorre enquanto construção das relações que nos caracterizam como seres-no-mundo: relação com a natureza e relação com os outros humanos. Isso significa que liberdade individual e liberdade relacional são duas dimensões inseparáveis. A primeira consequência disso é que a liberdade humana só é liberdade "realizada" enquanto liberdade no mundo natural e social, ou seja, quando ela se faz o fundamento que alicerça a relação com a natureza e a vida comum dos sujeitos entre si. Nesse sentido, a "realização histórica da liberdade" se revela como o princípio e o fim normativos de todas as formas de configurar nossa vida coletiva (OLIVEIRA 2008, p. 41 et seq.).

Dessa forma, se a liberdade, no primeiro momento, é "transcendência" do eu frente a tudo que é fato, como dizia Hegel $(1955,5$, p. 30) essa liberdade é a liberdade do vazio e da 
destruição, pois frente a ela toda realidade se dissolve; se, num segundo momento, ela é "decisão", tomada de posição frente a uma multiplicidade de possibilidades, contudo, ela só se plenifica verdadeiramente quando se exterioriza, faz-se mundo e se autoconfigura como ser efetivo na natureza e na sociedade, na esfera do mundo objetivo. "O sujeito só existe enquanto marcado e configurado pelas estruturas constitutivas de seus mundos históricos (relações institucionais)" (OLIVEIRA, 2008, p. 254). A liberdade é, assim, o evento histórico da produção comum de estruturas, de instituições, que efetivam o ser humano como ser da autodeterminação.

Liberdade é o processo por meio do qual o ser humano conquista seu ser e este é a razão de ser última de nossas ações no mundo. Portanto, liberdade efetiva é liberdade enquanto construção intersubjetiva de relações, isto é, a construção do ser pessoal como sercom-o-outro e, por isso, decisão a respeito da "configuração específica deste ser-com". Afirmar isso significa dizer que o ser humano é luta permanente de conquista de sua liberdade, portanto ele é essencialmente um "ser de risco" porque determinadas configurações deste ser-com podem ser a "negação da igualdade e liberdade" proclamadas como princípios normativos desse processo de conquista de si.

Assim, o que está em jogo no processo de libertação e que torna possível a constituição dos sujeitos enquanto sujeitos é esse "processo de construção de comunhões", como espaços de efetivação da liberdade na contingência dos eventos, das situações e das coisas, a sempre renovada busca de uma configuração num momento histórico determinado e, por isso, único. A liberdade, então, só é livre enquanto história da luta pela produção das “obras" que constituem formas de efetivação de nossas vidas Por essa razão, uma liberdade somente interior não é, propriamente, liberdade, mas ela é efetiva quando é unidade de ambos os aspectos, da universalidade e da particularidade, do pensamento e da ação, da transcendência e do engajamento, da possibilidade e da realização, que são momentos de uma mesma totalidade.

Se a liberdade é, assim, um processo que se efetiva enquanto síntese de opostos, ela encontra seu grau supremo de efetivação na conquista da subjetividade dos sujeitos, na esfera do mundo das relações sócio-políticas construído pelo ser humano. A condição disso é a superação de qualquer forma de "coisificação do ser humano" e a criação de um mundo em que os sujeitos se reconheçam, mutuamente, como seres fundamentalmente livres e iguais e se respeitem mutuamente como entidades que não devem ser reduzidos a puros meios, instrumentos uns dos outros, mas respeitados como fins em si mesmos. Nesse horizonte, 
entende-se a afirmação forte de H. Krings (1973, p. 493) a respeito da compreensão do mundo moderno: "A liberdade é o programa da humanidade moderna [...] Desde então a liberdade é um tema central da filosofia como da política". No entanto, a luta revolucionária pela liberdade desembocou não raramente em sistemas de coerção de tal modo que a modernidade, a época da autolibertação do ser humano, é marcada por uma contradição até hoje não superada (p. 494).

Com isto tocamos o cerne do processo de efetivação histórica da liberdade, que deve ser a vida humana: ser homem significa conquistar-se como ser livre e o caminho para chegar aí passa pela superação do indivíduo como realidade isolada e pela construção com os outros de um mundo que seja efetivador da liberdade. Aí cada um é para si pela mediação do outro, cada um existe para si enquanto existe pelo outro e para o outro. Isso significa construir uma intersubjetividade simétrica que é síntese da identidade (todos são considerados como fins em si mesmos) e da diferença (todos são reconhecidos nas diferenças que não destroem a igualdade básica).

O sujeito, assim, se constitui enquanto sujeito pela mediação do encontro com o outro sujeito o que significa dizer que a conquista de uma subjetividade verdadeira só é possível quando se opõe às desigualdades vigentes um "princípio de igualdade de direitos" fundado na liberdade. Tem razão Hegel, quando sabe que, ali, onde o humano se divide em senhor e escravo, não é possível emergir a liberdade verdadeira (OLIVEIRA, 2015, p. 226 et seq.).

Uma vez trabalhada a questão das características fundamentais do indivíduo humano enquanto ser pessoal, que assim se revela uma configuração de fatos primos, põe-se a questão fundamental de sua unidade. O central nesta problemática é a questão do ponto de unidade: "[...] a configuração que constitui o indivíduo humano como pessoa humana se apresenta, numa primeira aproximação, como o ponto de intersecção de todos os fatos primos mencionados ou das formas às quais eles devem ser associados", isto é, todos esses fatos primos se encontram em um ou dentro de ou como um ponto no qual consiste a unidade do indivíduo ou da pessoa" (PUNTEL, 2008, p. 367).

Esse fato configurador é o "dizer eu” entendido em seu caráter ontológico enquanto derivado das primeiras características essenciais, a inteligência e a vontade, que são fundamentalmente coextensividade intencional com o universo ou com o Ser em seu todo, fator que é decisivo para mostrar a impossibilidade de redução do ser humano à dimensão puramente física ou biológica. Precisamente enquanto ente corporal-espiritual, o ser humano possui não simplesmente um meio ambiente, como os animais, mas um mundo irrestrito, o 
universo, o Ser em seu todo e, assim, a capacidade de superação permanente. Puntel (2008, p. 368) denomina o ponto de unidade do ser humano de sistemático porque o ser humano, assim compreendido, é a única configuração capaz de autossituar-se no sistema, no Ser em seu todo.

\section{A ESPECIFICIDADE DA ATIVIDADE ECONÔMICA}

O ente biológico é condicionado pelas fases da vida entre o nascimento e a morte e se revela nesse processo como um ser fundamentalmente caracterizado pela capacidade de abertura ao outro e acolhida do outro (ARISTÓTELES, De Anima III, 2), de contato com a alteridade. Ele não pode garantir sua autoconservação sem receber o outro e agir sobre ele: “Plantas e animais sempre têm um determinado 'meio ambiente', no qual eles vingam e com o qual eles se encontram em permanente intercâmbio. Esse meio ambiente constitui o 'horizonte' bastante restrito desses seres vivos. Eles não são capazes de 'olhar para fora' ou atuar para além dos limites desse meio ambiente" (PUNTEL, 2008, p. 366). Todos os seus órgãos estão a serviço da sobrevivência do todo, o que o revela como um sistema autorreferencial que, por um lado, se diferencia de seu meio ambiente, mas que, por outro lado, não pode sobreviver sem ele.

Tudo isso constitui a materialidade, a dimensão psicofísica e a dimensão biológica do sujeito humano que estruturam e constituem todo seu ser, objeto de investigação das ciências empíricas. Essas dimensões, contudo, são dimensões de um ser extremamente complexo, portanto constituem elementos do todo do ser pessoal de tal modo que também a estrutura de suas necessidades se diferencia fundamentalmente da dos outros animais, assim que o subsistema da economia vai muito além do que exige o metabolismo dos entes biológicos. Por exemplo, de um lado, as necessidades físico-biológicas nos compelem à sociabilidade, indispensáveis para a satisfação das necessidades, mas, por outro, podem levar à comparação da satisfação das necessidades dos outros e ao desejo ou de atingir o mesmo patamar ou de superá-lo com grandes consequências na vida humana (HÖSLE, 1997, p. 568 et seq.).

A eficiência do processo é assegurada pela técnica que é um procedimento voltado para a transformação dos bens da natureza e para a fabricação de ferramentas e máquinas. Mesmo as técnicas mais sofisticadas não criam os recursos, mas apenas os transformam, o que significa dizer que a transformação não pode ultrapassar determinados limites relativos à estruturação da natureza sob pena de provocar graves danos para a natureza, que é a primeira fonte de todo bem-estar, e, consequentemente, para a vida humana. Essa é a raiz da questão 
ecológica que é absolutamente central para a sobrevivência da humanidade (HÖSLE, 1991, p. 96-120).

A atividade econômica se efetiva num contexto social marcado por uma multiplicidade de costumes, de formas de comportamentos, de normas que estabelecem o quadro em que se inserem os agentes econômicos: produtores, consumidores e instituições. Dessa forma, segundo Pilz (1974, p. 13), pode-se entender uma ordenação econômica ou um sistema econômico como a totalidade de todas as regras e instituições vigentes na construção e na evolução da economia. Assim, a economia se mostra como uma parte do todo social que se articula e se efetiva através de normas reguladoras.

As sociedades modernas são caracterizadas, do ponto de vista da economia, por uma crescente especialização de atividades, o que traz consigo uma troca complicada de bens e serviços de modo que o processo de produção se efetiva como um forte processo de estruturação de relações sociais. O resultado desse processo de produção é determinado pelo estoque e a qualidade dos recursos, ou seja, dos fatores de produção. Os economistas costumam distinguir três fatores fundamentais desse processo: o potencial das forças de trabalho, os meios de produção e os recursos (PILZ, 1974, p. 17). Além disso, a divisão do trabalho gera a formação de categorias e classes, cujos membros, na base de estilos de vida semelhantes, de formas de trabalho, do poder econômico e do lugar que ocupam nas relações sociais de produção, possuem interesses comuns e organizam associações que constituem uma mediação entre a família e o Estado e conduzem à formação de uma sociedade de classes com seus interesses específicos. Isso exerce uma função fundamental no processo da atividade econômica e nas lutas de suas classes sociais na defesa de seus interesses específicos dentro do contexto estrutural em que se situam. Nesse contexto emerge a categoria de "propriedade", que é especificamente humana, pois, indo além do uso imediato ou da posse, gera uma relação entre o ser humano e uma coisa que torna possível a transcendência de uma situação de necessidade atual (HÖSLE, 1991, p. 570-571).

Nas sociedades modernas, marcadas pela divisão de trabalho, hoje em nível internacional, milhões de bens e serviços são diariamente trocados no mercado através de dinheiro. O mercado se revela aqui, então, como o lugar das trocas, e o dinheiro o meio utilizado para as trocas, cuja eficiência depende do aparato tecnológico e de normas adequadas. A atividade econômica, realizada com meios escassos, destina-se, em princípio, à cobertura, com qualidade, prioridade e volume, das necessidades diferenciadas dos indivíduos 
e das comunidades. A escassez de meios implica decisões sobre sua repartição no que diz respeito às necessidades individuais e sociais do presente e do futuro.

A atividade econômica, quando realizada em sociedades complexas, põe uma questão decisiva que é a fonte da diferença estrutural entre sistemas econômicos: a questão da coordenação, do controle e da orientação das inúmeras e diferenciadas atividades econômicas. O problema central aqui é precisamente o do mecanismo de coordenação que necessita, para poder funcionar, de um sistema de informações e sanções. A combinação de todos esses elementos é aquilo que se pode denominar um "modelo econômico". O modelo econômico hegemônico na modernidade ainda é o chamado de "pura economia de mercado" e foi teorizado pelo "liberalismo clássico" (A. Smith, D. Ricardo, J. B. Say, J. S. Mill).

Essa teoria se situa num contexto político de profundas transformações provocadas pelo movimento do Iluminismo centrado na reivindicação por autonomia e liberdade em contraposição aos regimes absolutistas vigentes. O Liberalismo partia de uma visão do ser humano enquanto indivíduo racional, capaz de atuar racionalmente e, com isso, portador do direito de liberdade (PILZ, 1974, p. 23). Do ponto de vista jurídico, a economia de mercado se caracteriza pela "propriedade privada" dos meios de produção, pela liberdade do consumidor, liberdade de comércio, de escolha de profissão, de trabalho e de concorrência.

O ponto de partida da tese fundamental de uma economia de orientação liberal é a consideração da liberdade de cada indivíduo na busca da satisfação de suas necessidades e desejos na base de seus recursos e conhecimentos sem qualquer plano imposto pela instância estatal. A tese aqui é que há um mecanismo impessoal (Smith utiliza aqui a metáfora da mão invisível) que garante uma lógica interna de funcionamento na aparente desordem proveniente do entrelaçamento dessas inúmeras atividades. Essa ordem estrutural garante, na linguagem da teoria econômica neoclássica, a alocução eficiente dos recursos produtivos. Isso significa dizer que, quando cada indivíduo busca seu próprio interesse, faz-se, por mediação do sistema de preços, a coordenação dessa multiplicidade imensa de atividades com a exclusão de qualquer intervenção estatal.

Esse mecanismo, "princípio-eixo" da economia liberal, é precisamente o "mercado" que, assim, é tratado como um princípio de articulação de um determinado paradigma econômico, o paradigma liberal, diametralmente contraposto ao paradigma da economia baseada na intervenção estatal que é excluída a não ser a que se destina ao fortalecimento do mercado, à consolidação dos interesses do capital e à ampliação da abertura comercial e financeira. Economicamente, essa proposta exigia o "jogo livre de forças" em relação às 
forças de trabalho, ao dinheiro e aos bens e serviços. Isso implica que o trabalhador poderia empregar sua força de trabalho como quisesse, e os possuidores de dinheiro poderiam empregá-lo de acordo com seus interesses. A oferta e a procura são reguladas pelo mercado e pela formação de preços que, para essa teoria, constitui a única fonte confiável de informação numa economia complexa (lei da oferta e da procura).

Tomaremos aqui a distinção de Braudel (1996), já antecipada por Marx nos Grundrisse, entre economia de mercado e sistema de mercado. A partir dessa realidade básica da vida humana, é possível distinguir entre economia de mercado e economia capitalista (sistema de mercado). À economia de mercado pertencem as trocas cotidianas, os circuitos locais, trocas transparentes que reúnem produtores e consumidores. Mercado é, portanto, o lugar onde ocorrem trocas econômicas desde que grupos humanos conseguiram bens muito mais do que necessário e começaram a trocar por outros produtos com grupos vizinhos.

O que caracteriza as sociedades tradicionais, pré-capitalistas, é que aí o mercado ocupa um lugar secundário na economia, não constitui a instância básica de integração social uma vez que a produção está voltada à satisfação das necessidades das comunidades, e somente o excedente é destinado ao mercado. Na economia capitalista, ao contrário, vigora o "sistema de mercado", ou seja, os produtores não produzem mais para o seu consumo, mas para trocar no mercado, e assim o mercado se faz o cerne da economia, o elo entre as diferentes atividades, a instância constituinte da sociabilidade, portanto produtora da integração social, a base que transforma todas as relações sociais em relações mercantis.

Isso significa dizer que "a produção não se faz em função da satisfação das necessidades humanas, mas é um movimento de autovalorização do valor, um processo autônomo, autorreflexivo [...]" (OLIVEIRA, 1995a, p. 16). Enquanto tal o valor se faz o sujeito de todo o sistema, e as mercadorias se tornam mediação das relações sociais (OLIVEIRA, 2015, p. 248 et seq.). Para Marx, segundo Flickinger (2003, p. 28), o modelo capitalista de mercado "funciona única e exclusivamente à base da abstração das qualidades características dos produtos avaliados a partir da qualidade do trabalho humano neles inscrita. A mercadoria perde, portanto, a relação com sua origem no trabalho humano, transformandose em mero quantum". Para Marx, esse processo mercadológico significa a "submissão do ser humano livre às exigências da ordem econômica do capital”. 


\section{NEOLIBERALISMO: O PROJETO ATUAL DO CAPITALISMO}

O projeto fundamentalmente consiste na implementação radical do que se denomina Liberalismo econômico. Essa corrente de teoria econômica é conhecida como a Escola de Chicago que tem, contudo, seus fundamentos filosóficos nas teses da assim chamada Escola Austríaca, cujo principal expoente é Ludwig von Mises. Tese básica: o direito de propriedade é o único direito universal, fundamental e absoluto que começa com o direito absoluto do próprio corpo e inclui todos os bens que se possam adquirir. Como diz Macpherson ${ }^{10}$, o indivíduo, na concepção da filosofia política moderna ${ }^{11}$, é, por sua constituição ontológica, o proprietário exclusivo de sua pessoa e de suas faculdades ${ }^{12}$. O indivíduo é assim, enquanto senhor de si mesmo, fundamentalmente um proprietário: “[...] uma pessoa é a única proprietária de si mesma. Se sou senhor de mim mesmo, devo ser senhor do meu trabalho [...] Mas, se sou dono do meu trabalho, devo ter o direito aos seus frutos [...] é errado que eu sacrifique meus direitos em favor do bem-estar alheio" (SANDEL, 2012, p. 84, 85, 89). Deste direito se derivam o direito absoluto de não agressão à propriedade e o direito de defender a propriedade $^{13}$.

Para W. Kersting (2005, p. 43) trata-se no liberalismo contemporâneo, que ele prefere chamar de libertarianismo, de um "absolutismo de propriedade" que provém de J. Locke. Sua raiz filosófica é o conceito de autopropriedade (self-ownership). Trata-se nessa posição de derivar o direito de apropriação e de processamento de um objeto do direito de propriedade em relação à própria pessoa: “o princípio de autopropriedade implica o direito absoluto dos indivíduos de dispor de si mesmos, do seu corpo, dos resultados de suas apropriações legítimas e dos frutos de seu trabalho".

A tese da autopropriedade transfere as propriedades normativas da pessoa à propriedade das coisas, o que significa colocar a propriedades das coisas sob a proteção do direto natural, portanto como algo inalienável à liberdade de tal modo que qualquer violação do direito de propriedade equivale a uma violação da liberdade de seu proprietário. Isso

\footnotetext{
${ }^{10}$ Retomando a tese fundamental de S. Mill (1990, p. 75) de que o indivíduo é soberano sobre si mesmo, sobre seu corpo e seu espírito.

${ }^{11}$ Cf. Oliveira (2010, p. 181-199).

12 É o que Macpherson (1979) articulou como "individualismo possessivo".

${ }^{13}$ Sobre a crítica de Ch. Taylor a respeito dessa maneira de concebermos o ser humano e suas consequências sobre a concepção de sociedade pensada tendo, no centro de seu sistema jurídico, o "indivíduo autônomo", confira Taylor (1989, p. 195 et seq.). A. Sen (2000, p. 86) chama atenção para as consequências terríveis de tal posição: "Como é mostrado em meu Poverty and famines, por exemplo, até mesmo gigantescas fomes coletivas podem ocorrer sem que os direitos libertários (incluindo os direitos de propriedade) sejam violados".
} 
significa equiparação de propriedade e liberdade. "Num sistema de propriedade absoluta, dos direitos de disposição capitalista absoluta, a propriedade não é mais algo exterior ao proprietário; o proprietário a incorporou, ela é seu corpo, ela é ele próprio. O revés dessa humanificação da propriedade é a coisificação dos sem propriedade [...]. Isso resulta numa economização ilimitada da liberdade" (KERSTING, 2005, p. 42-45).

Flickinger, inspirando-se em Hegel, defende a tese de que a sociedade civil do mundo moderno é estruturada enquanto constituída por duas esferas distintas, por dois campos que constituem as duas faces da mesma sociedade civil, cujos princípios se contrapõem: em primeiro lugar, o campo jurídico-legal, radicado no princípio da liberdade que tem a ver com a proteção do exercício consciente da vontade livre dos indivíduos que se reconhecem uns aos outros como pessoas livres e iguais ${ }^{14}$. Nesse espaço social, portanto, as pessoas agem enquanto seres autônomos, pois são portadoras de uma vontade livre e constroem seu interrelacionamento de forma consciente, com "a capacidade de decidir livremente quanto ao seu próprio futuro social e material”. Aqui a liberdade é o princípio estruturador do todo.

O outro campo essencial da sociedade civil é o material-concreto que é "regido por um processo de estruturação social ao avesso da consciência humana, pois encaminhando por necessidades intrínsecas ao campo da reprodução material-econômica, do sistema de divisão de trabalho e do mecanismo do mercado". Dessa forma, nesse nível, o intercâmbio é forçado uma vez que marcado pelas regras do jogo econômico, ou seja, por "um mecanismo de sociabilidade que escapa às determinações conscientes do homem", há uma impotência objetiva do direito no que diz respeito à configuração da sociabilidade material. Aqui os sujeitos são reduzidos a meros elementos economicamente calculáveis, ou seja, o ser humano livre é transformado em mera coisa material e o direito não tem como intervir nesse campo no qual a liberdade é ameaçada. Essa dualidade constitui o cerne do liberalismo moderno marcado por um abismo entre as suas duas esferas, entre o princípio da legalidade e o da justiça social.

Aqui emerge uma pergunta fundamental: “como é possível conciliar a liberdade pessoal com um sistema amarrado à necessidade do trabalho, às exigências criadas pela interconexão complexa da produção econômica e a uma lógica peculiar ao mundo da mercadoria?" Para Flickinger (2003, p. 17), a garantia de liberdade para todos só funciona sob

\footnotetext{
${ }^{14}$ Cf. Catatharino (2010, p. 309): "No terreno jurídico-administrativo, a ordem liberal realiza-se por intermédio da instauração do estado de direito que constitui a associação político-governamental mais adequada para a implantação da justiça e a única forma de organização jurídica capaz de permitir a convivência livre e harmoniosa da pessoa humana."
} 
determinadas condições, e a fundamental é que ela "deixa inteiramente de lado o avesso das relações sociais, que é o da constituição material da sociedade [...] Levanto com isso a suspeita de que, ao preocupar-se exclusivamente com a proteção da vontade livre das pessoas [...] como diz Hegel, o próprio direito liberal não tem condições de determinar também as regras do jogo material-econômico".

Daí a questão central da sociedade liberal: “[...] a sociedade civil dá a impressão de basear-se em uma contradição insolúvel, firmada, por um lado, na vigência da ideia da liberdade de seus membros e, por outro, no processo de objetivação do homem segundo a lógica da economia política.” (FLICKINGER, 2003, p. 22-29). Na visão do pensamento político liberal, a primeira instituição é condição de possibilidade da outra: “O estado de direito é a mais importante instituição da ordem liberal, sendo a condição necessária para o bom funcionamento da economia de mercado e para a instauração de uma democracia representativa que não se torne despótica." (CATATHARINO, 2010, p. 310).

Para os neoliberais, assim como não podemos julgar boa ou má a lei da gravidade, do mesmo modo não podemos julgar as leis do mercado: "elas simplesmente se impõem a nós, portanto [...] o mercado não pertence ao campo das ações e interações humanas e sociais" (SUNG, 2018, p. 130), é algo superior e incontrolável, e dessa forma não tem sentido aqui levantar questões éticas que pertencem a outro nível. A única questão aqui é sua eficiência técnica. O mercado é compreendido como um mecanismo auto-organizador, e enquanto tal sua avaliação tem como critério a eficiência e não a valoração ética. Suas regras constituem um mecanismo semelhante às leis da natureza: elas são algo objetivo que o ser humano não tem condições de modificar. Por essa razão, devemos estudar a ação humana e a cooperação social como um físico estuda as leis da natureza (naturalismo epistemológico).

Não há direitos fora das leis do mercado. Portanto, a desigualdade e a exclusão nada têm a ver com injustiça social. Assim, a pobreza não é um problema ético, mas uma incompetência técnica. O maior erro dos opositores do capitalismo é assim a acusação de injustiça social baseada na ideia de que "a "natureza" concedeu a todas as pessoas certos direitos só pelo fato de terem nascido". Por essa razão, no que toca à distribuição da riqueza, “[...] não tem sentido referir-se a um suposto princípio natural ou divino de justiça" (MISES, 2008, p. 80-81).

O Estado, quando me obriga a pagar impostos para garantir os chamados direitos sociais (moradia, escola, saúde, etc.) me obriga à solidariedade social e cria parasitas que 
vivem da minha propriedade. Assim, o imposto é uma forma de confisco da propriedade ${ }^{15}$. Portanto, nem saúde, nem educação, nem previdência, nem segurança pública, nem justiça se legitimam enquanto financiados pelo Estado. Os pobres não passam de indivíduos que escolheram objetivos errados ou estratégias não adequadas, ou seja, são indivíduos que por culpa própria perderam a competição com outros. Assim, o mérito (a meritocracia) emerge como único critério de ascensão social. Há muitos perdedores na sociedade que são fracassados e vivem a exigir privilégios.

Para o neoliberalismo, o Estado é visto como o grande usurpador da propriedade e, enquanto tal, produtor de violação à liberdade, e por isso é radicalmente desqualificado como ator fundamental da vida econômica e social (SAVIDAN, 2010, p. 157) e a única instituição eticamente aceitável na esfera da atividade econômica é o "mercado livre", ou seja, um mecanismo que respeita a liberdade que é um direito fundamental de cada ser humano. Todos, no mercado livre, têm os mesmos direitos. Cada indivíduo é o único responsável por seus objetivos e pelas estratégias escolhidas para alcançá-los.

Como isso se traduziu depois num projeto de sociedade? Esse projeto foi pensado nos anos quarenta sobretudo por F. von Hayek e M. Friedman (1961), e o objetivo fundamental foi contrapor-se ao surgimento do que se chamou o "Estado de bem-estar social" articulado basicamente a partir das ideias do economista britânico J. M. Keynes com o objetivo principal de salvar o capitalismo marcado por uma profunda crise desde os anos 20 do século passado decorrente de problemas criados pela lógica de exclusão e concentração de riqueza do mercado e das reivindicações nesse contexto da classe trabalhadora. Essas propostas do liberalismo econômico ficaram esquecidas até que o capitalismo entrasse de novo em crise nos anos 70 .

A ideia básica que moveu Keynes (1992) era que a insuficiência da demanda que marcava o capitalismo em crise só poderia ser superada através de uma política de pleno emprego e de redistribuição de riqueza (promoção do consumo para manter a acumulação, a eficiência econômica). Para que a economia pudesse atingir isso, foi necessária a intervenção do Estado como regulador e parceiro, ou seja, intervenção nos mecanismos do mercado através de políticas econômicas e sociais de algum modo limitadoras de sua lógica. Sem dúvida, aqui também o mercado é visto como o sistema econômico que produz maior

\footnotetext{
15 Cf. Sandel (2012, p. 80): “O Estado não tem mais direito de forçar o contribuinte abastado a apoiar os programas sociais para o pobre do que um ladrão benevolente de roubar o dinheiro do rico para distribuí-lo entre os desfavorecidos".
} 
eficiência produtiva, mas não é sempre um sistema justo na distribuição. Assim, o Estado aparece como o grande parceiro do mercado que, através de suas intervenções, tem condições de minimizar crises econômicas e recessão e agir na direção de enfrentar os problemas sociais aqui gerados.

O grande mecanismo do Estado de Bem-Estar Social para realizar isso foi a criação do que se chamou de "Fundo público" para operar de duas maneiras básicas: financiamento da reprodução e acumulação do capital, o que levaria a aumentar a taxa de lucro; e financiamento da reprodução da força de trabalho através do que se chamou o "salário indireto", as chamadas políticas sociais: educação gratuita, medicina socializada, previdência social, etc.

Trata-se de uma forma de articular a economia através do financiamento simultâneo do capital e do trabalho. Durante a Segunda Guerra Mundial foi publicado na Europa o relatório de Beveridge propondo um sistema universal de luta contra a pobreza, que assim articulou os objetivos dessa forma de organizar a economia. Assim, o Estado de Bem-Estar foi instalado por meio das seguintes estratégias: 1) intervenção do Estado nos mecanismos de mercado; 2) política de pleno emprego (melhoria dos rendimentos dos cidadãos); 3) institucionalização do sistema de proteção; 4) institucionalização de ajudas para os que não conseguem estar no mercado de trabalho (CORTINA, 2005, p. 54).

A partir daqui se articulou na Europa a ideia do que se chamou "Estado Social de Direito", que consiste basicamente em incluir no sistema de direitos fundamentais não só as liberdades individuais, direitos civis (direitos negativos que protegem as pessoas contra as usurpações ilegítimas do Estado) e os direitos positivos políticos, (direitos que garantem a participação na formação da vontade pública), mas também os direitos econômicos, sociais e culturais (direitos positivos ou direitos à prestação, direitos sociais) (RICOEUR, 2006, p. 213): satisfação das necessidades básicas e acesso a bens fundamentais para todos como exigências éticas a que o Estado deve responder, o que só é possível através de intervenção (pode-se falar aqui de uma justificação ética das políticas sociais). Aqui a tese básica é de que é possível e irrenunciável proteger os direitos sociais que caracterizam a cidadania social: a satisfação de necessidades básicas e acesso a bens fundamentais a todos os membros da sociedade, o que implica que o Estado se torne um Estado interventor no campo econômico e social e pressupõe a consciência de sua corresponsabilidade na condição social da sociedade, sobretudo de seus membros mais vulneráveis.

O resultado desse processo foi o aumento da capacidade de consumo das classes menos favorecidas. E com isso nasce o que se chamou consumo de massa. Isso levou a um 
endividamento do Estado e nos anos 70 a uma profunda crise causada por muitas razões (OLIVEIRA, 1995a, nota 19, p. 39-40), entre as quais uma fundamental foi gerada pelo fato de que os grandes oligopólios transnacionais não enviaram os lucros obtidos para seus estados de origem, e assim não alimentaram os fundos públicos nacionais.

Essa crise violenta dos anos $70^{16}$ foi chamada de "colapso da modernização" e provocou o reaparecimento das teorias econômicas elaboradas nos anos 40. Este foi o fenômeno que se denominou de "Neoliberalismo" que atribui o fundamento da crise à atuação do Estado, o que consequentemente conduziu à implantação insuficiente do mercado. $\mathrm{O}$ básico nessa proposta é a eliminação do duplo financiamento que caracterizou a fase anterior. Agora o financiamento se dirige exclusivamente ao capital: o neoliberalismo corta o fundo público no polo do financiamento dos bens e serviços públicos, corte do salário indireto (os programas de bem-estar social) através de reformas.

Para os adversários do "Estado Social" a insistência no financiamento dos bens e serviços públicos, políticas consideradas irracionais e populistas, de fato produz menos crescimento e mais desemprego a longo prazo, que são o resultado da não consideração da escassez de recursos e da lógica de funcionamento dos mercados. Assim, a recomendação agora para os mercados financeiros é a desregulamentação e a eliminação das barreiras à entrada e à saída do capital-dinheiro; para os mercados de trabalho, a flexibilização e a remoção das cláusulas sociais. Daí o desmonte radical de tudo o que no passado signifícou positivação de direitos.

O objetivo fundamental agora é maximizar o uso da riqueza pública nos investimentos do capital, o que faz com que os direitos sociais tendam a desaparecer, uma vez que considerados gastos inaceitáveis porque perturbadores da acumulação do capital e, assim, do progresso econômico. Por outro lado, defende-se a redução das alíquotas de impostos sobre os maiores rendimentos, impostos mais baixos para os ricos (o sistema tributário estimula a especulação, e não o trabalho), desregulamentação dos mercados de trabalho, políticas que aumentam as riquezas para os mais ricos (servem ao 1\% mais rico), ampliam a desigualdade econômica e não produzem o crescimento prometido.

Uma das políticas fundamentais é a concentração excessiva no controle da inflação e do orçamento, ignorando as reais ameaças à prosperidade econômica que são a crescente desigualdade, o subinvestimento e fosso crescente entre produtividade (aumento de $161 \%$ em

\footnotetext{
${ }^{16}$ A respeito dessa problemática da crise do Estado Social, cf. Flinckinger (2003, p. 34-36).
} 
40 anos) e salário (19\%). 80\% dos empregos conseguidos é atividade de baixa remuneração. O problema é mundial e nacional, plenamente demonstrado no caso dos Estados Unidos, vistos como modelo, pelo relatório planejado e coordenado pelo prêmio Nobel de economia J. Stiglitz (2015) mostrando também que é possível reduzir a desigualdade e ao mesmo tempo melhorar o desempenho econômico.

A proposta do neoliberalismo conduziu a uma cruzada global contra a intervenção estatal: “[...] apenas um Estado mínimo, limitado a fazer cumprir contratos e proteger as pessoas contra a força, o roubo e a fraude, é justificável” (NOZICK, 1974, p. ix) ${ }^{17}$ e os direitos sociais e econômicos criados pelas políticas do Estado Social, que, segundo seus adversários, constituem um obstáculo à operação das leis de concorrência e por isso são políticas irracionais e populistas, infrações ilegítimas da liberdade individual (FRIEDMAN, 1961, p. 111). Elas, a longo prazo, produziriam menos crescimento e mais desemprego e por isso devem ser substituídas por políticas que não se contraponham às hipóteses científicas do indivíduo utilitarista. Por isso, os defensores do "mercado totalmente livre" (considerado condição para a realização do ser humano enquanto ser livre) se contrapõem radicalmente a essas políticas consideradas ineficientes e perturbadoras do processo produtivo e, sobretudo, pelo que elas pressupõem: seu financiamento através de impostos. A razão do desastre é que aqui não se pode contar com um mecanismo simplesmente decisivo para o funcionamento da economia, o mercado.

Como se legitima aqui a primazia do mercado frente ao mecanismo do planejamento das atividades produtivas? O principal argumento dos neoliberais hoje é que o mercado exerce uma função epistêmica que o planejamento é incapaz de exercer, pois o planejamento pressupõe um conhecimento completo do mercado como condição de possibilidade da promoção consciente e voluntária do processo econômico. Dada a complexidade estrutural de uma economia moderna isso é impossível, por isso só um mecanismo inconsciente e automático pode resolver o problema. Assim, o mercado se revela como um mecanismo capaz de suprir a falta de conhecimento e assim impedir a anarquia, produzindo um processo produtivo como um processo coordenado. O mercado se revela, assim, como "o único meio de identificar e transmitir dados sobre a estrutura infinitamente complexa das preferências e dos recursos da sociedade" (CATATHARINO, 2010, p. 310).

\footnotetext{
${ }^{17}$ A respeito da concepção filosófica do Estado no liberalismo contemporâneo tanto em contraposição ao anarquismo como à teoria de justiça distributiva de Rawls articulada no pensamento de Nozick, cf. Araújo (2007, p. 272-286).
} 
Daí porque o caminho proposto tem que levar em consideração as restrições de recursos e o funcionamento dos mercados competitivos: desregulamentação dos mercados financeiros e eliminação das barreiras de entrada e saída do capital-dinheiro, flexibilização do mercado de trabalho e remoção de cláusulas sociais, política monetária controlada por um banco central independente, etc. Aqui está, diz J. M. Sung (2018, p. 16), "a grande novidade 'espiritual' e cultural do nosso tempo", é este o "novo espírito" do capitalismo, seus novos valores fundamentais em contraposição ao desenvolvimentismo anterior: confiar plenamente no mercado enquanto sistema auto-organizador que uma vez libertado de regulações e intervenções indevidas soluciona por si mesmo todos os problemas econômicos e sociais, satisfazendo "a sempre crescente gama de desejos" (HAYEK, 2007, p. 70). Desse modo, o mercado e não o ser humano é o construtor da história: no lugar de um sujeito consciente entra em cena um mecanismo inconsciente, impessoal, que é politicamente incompatível com a democracia. As atividades das organizações da sociedade civil, dos sindicatos, dos movimentos sociais são simplesmente inúteis, desprovidas de sentido, baseadas em conceitos primitivos. Além disso, qualquer tentativa de forçar maior igualdade econômica implica a destruição de uma sociedade livre (HAYEK, 1960).

Assim, o Neoliberalismo significa um processo de contração do espaço público dos direitos e um processo de ampliação dos interesses privados de mercado, o que levou a um aumento significativo do papel das ciências e da tecnologia no processo de produção e faz com que muitos cientistas sociais contemporâneos afirmem que a ciência e a tecnologia se transformaram nas forças produtivas mais importantes.

Nesse contexto se mostra que agora o eixo básico de nosso projeto de civilização é a subordinação da qualidade de vida dos seres humanos ao crescimento econômico (acumulação do capital). Aqui o aumento do PIB é o sinal mais claro de progresso. A sociedade do crescimento é igualmente a sociedade do consumo ilimitado e a ideia hoje difundida fortemente de que nisso consiste propriamente a felicidade humana. Os resultados desse processo ameaçam a vida humana e toda vida no planeta. A exploração ilimitada da natureza - cujos efeitos se mostram nas catástrofes socioambientais que experimentamos e constitui elemento central nesse modelo -, alerta-nos para o fato de que o modelo econômico vigente pode encaminhar a humanidade a um colapso ecológico-social.

Nesse contexto houve grandes transformações nas relações produtivas com revolução tecnológica, inteligência artificial, automação, indústria 4.0, digitalização da economia e a primazia do capitalismo financeiro em que o empresário produtivo cede lugar ao empresário 
rentista, cujo objetivo visa aumentar a rentabilidade se efetiva agora através de investimentos em títulos do tesouro, ativos financeiros e ações na bolsa de valores. Isso significa dizer que esse segmento do sistema econômico não contribui para a economia real com produção e geração de empregos. Tudo isso tem enormes consequências na vida dos trabalhadores que em grande parte são eliminados do processo de trabalho tanto porque desaparecem os antigos postos de trabalho como por falta de competência tecnológica para assumir os novos empregos. Surgem, assim, um novo tipo de empresário e um novo tipo de trabalhador com grande qualificação e especialização que são trabalhadores polivalentes. Fundamental nesse contexto é que, de qualquer modo, esse processo de transformação produtiva intensifica a exclusão de trabalhadores e está deixando milhões em situação de miséria (OLIVEIRA, 2010, p. 374 et seq.).

\section{A DIMENSÃO ÉTICA DA ECONOMIA}

Para Dardot e Laval (2016, p. 16), o neoliberalismo destrói regras, instituições, direitos, mas também gesta novos tipos de relações sociais, ou seja, novas maneiras de viver, novos comportamentos. W. Brown interpreta o neoliberalismo como uma nova formulação da razão normativa que consiste fundamentalmente em estender a todas as dimensões da vida humana essa formulação específica dos valores econômicos, práticas e métrica. Dessa forma, o mercado é estendido, como modelo ideal, a todo o campo da ação humana, e as pessoas são transformadas em atores econômicos, o que leva a leis que favorecem o mercado, desmontam qualquer tipo de organização popular de poder considerada como obstrução ao mercado livre, enfraquecem os princípios democráticos, reduzem drasticamente os investimentos em educação pública e saúde consideradas políticas vinculadas ao socialismo, transformam a eficácia econômica como o objetivo fundamental dos governos (BROWN, 2015, p. 30 et seq.).

O sustentáculo de todo esse processo é a constituição de uma subjetividade radicada nessa lógica econômica que se torna senso comum hegemônico nas sociedades, provocando o desaparecimento da ideia do bem público, comum a todos. Esse modelo normativo defende ardentemente liberalismo econômico, moralismo, autoritarismo, nacionalismo, ódio ao Estado, racismo. Isso nos levanta uma questão fundamental: que é a dimensão normativa? Como entender essa dimensão como momento da vida humana? 
Toda ética, portanto, pressupõe inevitavelmente uma concepção do ser humano. O que está fundamentalmente em jogo na ética é a conquista e a efetivação do ser humano enquanto ser livre, e isso significa a passagem da distância crítica do ser humano frente a qualquer fato para a configuração de sua vida histórica enquanto construção das relações que o caracterizam: relação com a natureza e relações com os outros humanos. O formalismo ético, de tipo kantiano, é capaz de demonstrar a validade incondicional das sentenças éticas, pois mostra que tal validade não tem fundamento empírico, ou seja, não depende nem de localização, nem da cultura, etc. No entanto, é incapaz de dirimir os conflitos humanos concretos, nas situações históricas específicas, em que ocorre a colisão de normas e é necessário um princípio que indique a prioridade. Tal princípio, só, pode ser, para uma filosofia em que a ontologia é uma dimensão irrecusável, o valor intrínseco de cada ente, o que nos leva a uma ética material de valores, que nos torna capazes de estabelecer uma hierarquia de bens e valores. O ser humano é em princípio aberto a toda e qualquer realidade, possui a capacidade de captar o valor intrínseco de tudo e consequentemente a possibilidade de um relacionamento com tudo de acordo com o valor intrínseco de cada realidade, o que constitui propriamente um comportamento ético.

É isto o que, com razão, Von Kutschera (1998, p. 303 et seq.) denomina "realismo de valores". O realismo de valores afirma que a existência de entidades de valor não depende de nossas preferências individuais fáticas o que, por outro lado, não significa que a existência de fatos de valor nada tenha a ver com a existência dos seres humanos como sujeitos receptivos e marcados por interesses, portanto com um mundo de valores que nada tenha a ver com o que nos diz respeito e nos move. O fundamental aqui é que, na tradição que defendeu essa posição, o que está em jogo no realismo de valores é a tematização de critérios para nossas preferências subjetivas e já se revela com clareza na diferença aristotélica entre os interesses fáticos de uma pessoa e seus verdadeiros interesses. Trata-se aqui de entender valores em sua dimensão ontológica e não como algo puramente subjetivo.

A primeira consequência disso, como foi anteriormente aclarado, é que a liberdade humana só é liberdade efetiva enquanto liberdade no mundo da natureza e da sociabilidade, ou seja, quando ela se faz o fundamento que alicerça a relação com a natureza e a vida comum dos sujeitos entre si, o princípio e o fim de todas essas configurações. Se a liberdade é transcendência sobre todo e qualquer fato, se ela é também tomada de posição frente a uma multiplicidade de possibilidades, no entanto ela só se plenifica quando se exterioriza, se autoconfigura como ser efetivo em nossos relacionamentos com a natureza e com a sociedade. 
A liberdade só é efetiva enquanto história da luta pela produção das obras que constituem formas de realização de nossas vidas: uma liberdade somente interior não é propriamente liberdade.

A liberdade encontra, então, seu grau supremo de efetivação na conquista da subjetividade dos sujeitos na esfera da cultura, isto é, do mundo das relações sócio-políticas construído pelo ser humano, o que constitui a tarefa ética suprema. Isso acontece quando os sujeitos superam qualquer forma de coisificação, de alienação, e se reconhecem mutuamente como seres fundamentalmente iguais e livres. Foi esse o grande passo teórico de Hegel frente à concepção de liberdade no pensamento transcendental em Kant e Fichte. Hegel, retornando aos gregos, vai recuperar o que ele denomina a "dimensão objetiva" da liberdade, ou, liberdade objetiva, que é o conjunto de instituições e comunidades por meio das quais a liberdade se efetiva no mundo da cultura, criado pelo ser humano (2015, p. 198 et seq.).

Ser homem significa, então, conquistar-se como ser livre, e o caminho para chegar aí é a construção de uma sociabilidade simétrica que seja síntese da identidade (todos sejam considerados como fins em si mesmos) e da diferença (todos sejam reconhecidos nas diferenças que não destroem a igualdade básica). Tem razão Hegel quando afirma que ali onde o humano se divide em senhor e escravo não é possível emergir a liberdade verdadeira.

a) A liberdade é o fundamento dos direitos humanos

O ser humano, como vimos, é aquela realidade que é fim em si mesma, o que não significa negar o valor próprio de cada realidade do universo. Precisamente porque aberto à totalidade do ser, ele é, então, "ponto de referência do universo", que é uma rede de relações na qual tudo tem a ver com tudo, e enquanto tal não pode ser reduzido a puro meio. Ele não é simplesmente um objeto entre outros objetos.

Se toda realidade é portadora de um valor intrínseco que corresponde à sua estrutura própria de ser, todo ser humano, enquanto ser inteligente e livre que consciente e livremente se possui a si mesmo, possui uma dignidade incondicional, que o faz portador no mundo do valor intrínseco supremo. Isso exige a dignificação ética do ser pessoal, fim em si mesmo, portanto portador de valor absoluto e de dignidade absoluta, e isso se diz de todo e qualquer ser humano o que fundamenta a "igualdade essencial de todos os seres humanos". Assim, todos são iguais porque livres, e por essa razão devem ser tratados de acordo com essa 
dignidade fontal, o que legitima uma ética estritamente universalista: “[...] o homem se constitui, portanto, sujeito de direitos ou sujeito universal" (LIMA VAZ, 2002, p. 209-210).

Que o ser humano não seja tratado como fim em si mesmo - por exemplo, ser tratado como puro meio para valorização do capital - contrapõe-se àquilo que ele é no mais profundo de si mesmo, equivale, portanto, a uma degradação de seu ser. Ora, é a dimensão do valor da constituição de cada ser, peculiar a cada ser, que é a base do valor propriamente ético de qualquer realidade. Por isso, a capacidade humana de captar as coisas como elas são em si mesmas, de exprimir sua inteligibilidade, é o que torna possível à vontade humana afirmar o valor do ser de uma realidade como valor ético. O ser humano age racionalmente ao afirmar um valor, quando seu ato se funda num valor do ser das realidades.

Assim, nesse agir no horizonte do todo em busca de seu ser próprio individual e social, deixar-se orientar pela consideração da constituição das diferentes realidades é o que constitui o caráter racional de sua ação. No caráter de ser livre que ele é se situa o fundamento de seus direitos fundamentais que são exigências nas diversas esferas de sua vida de efetivação de seu ser que ocorre quando suas ações fazem emergir obras em diferentes dimensões através de que ele efetiva seu ser. Aqui precisamente os direitos elementares constituem a base normativa de suas ações e do que elas produzem de modo especial das leis e das instituições; um critério, portanto, não simplesmente fático, mas normativo para o julgamento dos sistemas jurídicos e políticos que configuram de nossa vida coletiva.

Os direitos são direitos da pessoa enquanto pessoa, cuja constituição de ser se caracteriza por vincular a mais radical individualidade com a maior universalidade enquanto abertura à totalidade da realidade. Enquanto pessoa, o ser humano é, em primeiro lugar, um ser singular já que seu processo de individuação é positivo e interior: ele se fundamenta na liberdade enquanto aquela relação em que o ser humano se possui a si mesmo na forma da tarefa indeclinável de configurar seu próprio ser. Pessoa é liberdade, finalidade em si mesma e dignidade intrínseca suprema. Sua defesa é obrigação inevitável de cada um.

Por outro lado, na base de sua espiritualidade a pessoa é mais aberta de que qualquer outro ente, e sua autoefetivação ocorre na construção de obras comuns na história. Dessa forma, a comunidade política é uma decorrência da própria constituição ontológica do ser pessoal e por isto existe para obter um fim comum, a efetivação dos direitos fundamentais e inalienáveis de todos os seus membros. Assim, os direitos humanos articulam as exigências normativas que devem orientar a construção da vida comunitária. 
A gênese da liberdade é, assim, a gênese de uma sociabilidade solidária, enquanto reconhecimento mútuo de liberdades, o que significa dizer que a subjetividade se constitui através da comunhão de pessoas livres e iguais, ou seja, por meio de uma ordenação social radicada no reconhecimento universal, o que implica a eliminação de qualquer tipo de negação da subjetividade enquanto construção de uma vida social radicada na justiça e na solidariedade universal. Liberdade plena é liberdade historicizada, mundificada, exteriorizada em instituições, que regulam as relações constitutivas do ser humano enquanto ser humano e, assim, se manifestam como mediações históricas inelimináveis no processo de sua conquista.

Dessa forma, as configurações da liberdade nunca podem ser construídas a priori, mas devem ser buscadas criativamente nas diferentes situações históricas. Nesse sentido, liberdade é "imaginação criativa", que é em princípio inesgotável, e por isso podemos dizer que a história é história dos sujeitos e das instituições que eles produzem para poder ser. Portanto, nossa liberdade só é real pela mediação das obras no mundo, ou seja, enquanto processo de sua efetivação nas contingências da história por meio de suas produções. Nessa perspectiva, o processo de libertação emerge como um processo circular, sempre recomeçado, entre o horizonte de infinitude da liberdade enquanto transcendência e a finitude de suas realizações contingentes, que é produção de um mundo enquanto conjunto de obras, que gestam o espaço da liberdade efetiva. Assim, podemos dizer que o ser humano, ser da transcendência e do engajamento, em seu cerne, não simplesmente tem liberdade, mas é no mais profundo de si mesmo liberdade.

É enquanto ser pessoal, ser corporal, inteligente e livre, que o ser humano é portador de direitos inalienáveis, portanto radicados essencialmente na constituição de seu ser pessoal e enquanto tais devem ser considerados como naturais. Mas porque a pessoa é essencialmente um ser histórico, os direitos são sempre uma obra a se realizar na história. A consequência disso é que há sempre novos direitos a serem positivados e efetivados. Nomeiam-se hoje alguns desses direitos de que nos tornamos conscientes na atual situação do mundo: direitos da mulher, dos homoafetivos, das populações não brancas, dos marginalizados, dos excluídos, dos países e povos da periferia deste mundo, dos migrantes, das vítimas da globalização, das minorias, da natureza.

A partir dessa consciência, pode-se entender a tensão que existe entre o sistema de direito positivo e aqueles que, dentro desse sistema, não têm direito. Nessa perspectiva, a história humana se revela de ponto de vista normativo como o campo de luta pela efetivação de direitos, ou seja, sua transformação em direitos reais, criação de instituições que positivem, 
reconheçam e garantam direitos, portanto, pela efetivação dos seres humanos enquanto seres livres e consequentemente iguais. A conquista da humanidade do ser humano passa pela conjugação entre igualdade e liberdade, e enquanto tarefa histórica isso significa o enfrentamento de todo tipo de desigualdade e servidão.

Assim, a construção de uma sociedade igualitária no respeito às diferenças que não ferem a igualdade de dignidade e a criatividade é a exigência suprema que deve normatizar as lutas históricas. Trata-se, então, de estabelecer as condições de possibilidade da realização da integralidade do ser pessoal, de um mundo autenticamente humano, em que o respeito a cada ser humano e ao ser próprio da natureza constitui o horizonte que orienta a vida. Nesse sentido os direitos do cidadão emergem como o fundamento normativo universal da vida sócio-histórica e sua promoção e garantia como a tarefa básica da vida coletiva. O ser humano nunca será verdadeiramente ser humano enquanto for dependente e oprimido em qualquer dimensão de sua vida, e por essa razão não haverá fim da exploração e de todo tipo de opressão histórica que ameaça sua vida sem a efetivação dos direitos humanos.

Daí porque não há dignidade humana sem o fim da coerção material, da insegurança e da dependência econômica. Não há efetivação do ser humano sem o fim da dominação, das relações repressivas. Isso significa dizer que uma organização excludente da vida coletiva em que se naturalizam as desigualdades econômicas, sociais e culturais é incompatível com esse horizonte normativo que exige igualdade de direitos para todos, portanto relações sociais igualitárias e participativas.

b) A ética no horizonte da solidariedade universal

O espírito finito, enquanto ser racional, capta a racionalidade presente em tudo, já que tudo é principiado do princípio último, absoluto e consequentemente a hierarquia dos seres, que em consequência do entrelaçamento da verdade e do bem implica uma multiplicidade hierárquica de bens e valores sem o que é impossível resolver os conflitos na vida humana. Com isso demos um passo importante para além do simples universalismo formal das éticas da modernidade, pois a reflexão feita mostrou que a valoração ética das diferentes entidades com que nos confrontamos é irrecusável, quando se pretende ir além de um mínimo de normas inteiramente abstratas, o que significa e pressupõe a afirmação de que cada realidade possui um valor intrínseco. Isso só se pode afirmar a partir de um conhecimento das estruturas fundamentais dos entes, o que é a tarefa específica da ontologia geral. 
Nesse horizonte, cada realidade se revela como única, já que possuidora de uma forma de ser que lhe é própria. Por outro lado, em sua diferença de todas as outras realidades, encontra-se numa comunidade ontológica com todas as outras (?). É a partir dessa base metafísica que se pode fundamentar um horizonte ético capaz de dar uma orientação de vida ao homem contemporâneo.

O desafio crucial de nosso engajamento no mundo hoje tem, portanto, como pressuposto básico a fundamentação de um horizonte de universalismo ético de bens e valores, ou seja, a superação da redução da ética à esfera do privado e arbitrário através da fundamentação racional de uma ética universalista, não utilitarista, mas teleológica, que lhe fornece as bases racionais de um novo humanismo, capaz de enfrentar os desafios específicos à nossa época. O primeiro pressuposto (HÖSLE, 1999, p. 185 e ss.) para esse horizonte que nos vem de uma teoria ontológica, como a que foi esboçada, é que o ser humano é parte da natureza e a ela permanece sempre intrinsecamente vinculado tanto por sua gênese, como por sua forma orgânica de ser, o que tem consequências importantes não só para a consideração geral de suas ações, mas muito especificamente para o enfrentamento de um dos grandes problemas de nossa época, ou seja, para a relação "ser humano-natureza" (OLIVEIRA, 1996, p.173-202 ). Daí uma primeira consideração básica que nos vem da ontologia: o ser humano e a natureza são formas diferenciadas de participação no ser e de sua manifestação, o que implica dizer que o ser humano não é o único ser que possui valor intrínseco, portanto, que os seres da natureza devem ser reconhecidos em seu ser próprio, constituindo assim uma esfera de ser que não é redutível à esfera do ser humano.

Essa ontologia nova abre o espaço para uma nova postura ética ${ }^{18}$ que, para diferenciar com a postura moderna, poderíamos chamar de ontológica, cujo imperativo fundamental é: respeita cada ser em seu grau próprio de ser. A natureza, enquanto manifestação do Ser, é portadora de valores, e isso deve ser entendido do ponto de vista ontológico. A grandeza ontológica de um ente se mede pela abrangência de sua estrutura. Ora, pertence à estrutura do ser espiritual que ele seja coextensivo à totalidade do Ser, portanto sua abrangência é absolutamente ilimitada e universal. Isso implica que o ser humano não pode ser reduzido a apenas um meio para outros elementos do universo, mas antes é enquanto tal o ponto absoluto de referência do universo e é capaz de captar valores éticos e pautar sua vida por eles, ou seja, de ser um ser moral. Por essa razão, tratar o ser humano como um simples meio e não como

\footnotetext{
${ }^{18}$ A postura aqui defendida tem profundas afinidades e diferenças com a proposta de H. Jonas de fundamentar metafisicamente a passagem da filosofia da natureza para a ética. Cf. Jonas (1992, p. 128-146).
} 
fim absoluto em si mesmo significa uma degradação incompatível com sua estruturalidade ontológica, e isso também deve ser compreendido em primeiro lugar no plano estritamente ontológico e não ainda ético (PUNTEL, 2008, p. 393 et seq.).

A passagem do plano do valor ontológico para o valor ético só é possível para Puntel quando se leva em consideração que uma norma moral enquanto imperativo tem uma relação essencial a uma vontade. Um dever ser ou prescritividade sem uma instância que por assim dizer "faz" esta prescritividade é uma palavra vazia. Sem a mediação de uma vontade nenhum valor ontológico recebe um status moral, ou seja, o normativo-imperativo só emerge quando o agente eleva por meio do empenho de sua vontade os valores ontológicos a valores éticos. A partir, portanto, da qualidade ou da adequação do agir à estruturalidade ontológica do agente é feita uma norma. A racionalidade do ato pressupõe um fundamento ontológico, só se pode propriamente falar de racionalidade quando o estabelecimento da norma moral se pode fundar num valor ontológico basal. Portanto, a racionalidade ou a correção das normas morais depende de sua base ontológica. Sem o esclarecimento do nível ontológico as sentenças éticas são vazias (PUNTEL, 2008).

A questão, contudo, que se põe a partir daqui, é a seguinte: se para a validade de uma norma moral fundamental se exige uma decisão de uma vontade, como se deve pensar essa vontade? A vontade humana, individual ou coletiva, que é finita, não pode enquanto tal instituir uma norma de validade universal incondicionada de tal modo que ninguém está isento dela mesmo quando não é faticamente reconhecida. Só uma vontade absoluta não humana, a vontade do Absoluto concebido como ser pessoal, pode elevar os valores ontológicos a valores éticos.

Ora, a exigência primordial de uma ética fundamentada nesse horizonte é o do respeito a todo ser em sua forma de ser de tal modo que se garanta a coerência universal que constitui a estrutura básica do universo, o que contém uma ética de reconciliação universal que exige a superação de toda ordem social radicada na exploração e na injustiça social e ecológica, ou seja, radicada no objetivo único de um crescimento sem limites à custa da suprema exploração da natureza e da indiferença frente à pobreza e a miséria da humanidade. Este horizonte abre o espaço para uma militância no mundo que tem como tarefa básica restabelecer os vínculos rompidos com a natureza por nossa civilização técnico-científica (HÖSLE, 1991) e reconstruir as comunidades humanas de tal forma que se estabeleçam relações simétricas entre todos os seres humanos, nos diferentes níveis de organização de sua vida, ou seja, a efetivação da reconciliação universal entre os seres humanos precisamente 
através do reconhecimento, traduzido nas relações interpessoais e nas instituições fundamentais da vida coletiva, que efetivem os direitos de todos, da dignidade incondicional de todo ser humano, que é portador, no universo, do valor intrínseco supremo enquanto ser racional e livre. Dessa forma, revela-se como exigência ética suprema a construção de uma intersubjetividade simétrica e transitiva (OLIVEIRA, 2008, p. 120 et seq.), isto é, de uma humanidade reconciliada, portanto a exigência de humanização, da sociedade e de suas instituições.

Daqui se segue um segundo critério ético para o engajamento do ser humano no mundo: primazia entre os diferentes fins contingentes, que se oferecem à sua ação, têm os que efetivam o respeito à vida humana e à vida dos outros seres vivos, o que implica afirmar que as necessidades materiais básicas que se referem à manutenção e reprodução da vida humana se põem em primeiro lugar. Isso se contrapõe radicalmente à forma de organização hegemônica da economia em nossas sociedades, que é centrada no mercado e no lucro, pressupondo-se que a propriedade, o controle e a gerência privada e excludente dos meios de produção constituem a única forma natural e racional de organizar a economia, portanto, que são indispensáveis para a vida e o desenvolvimento humano. Essas necessidades, precisamente quando afastam obstáculos fundamentais para a posse de liberdades essenciais da vida humana (SEN, 2000, p. 27), têm prioridade em relação a qualquer outro tipo de necessidade, no sentido do mínimo exigido, o que por sua vez implica como consequência uma exigência ética em relação à economia: ela não é fim em si mesma, mas apenas o pressuposto material do desenvolvimento integral do ser humano e por isto deve estar a serviço das necessidades básicas, em última instância, a serviço da liberdade (SEN, 2000, p. 52 et seq.), e não simplesmente do crescimento econômico, que consequentemente se revela como meio e não como fim último da atividade econômica (OLIVEIRA, 1995a, p. 67 et seq.).

Isso implica que a economia não deve ser entregue a um sistema espontâneo, sem planejamento, participação dos cidadãos e regulação a não ser a competição de microentidades isoladas ou simplesmente ao comando central de uma burocracia administrativa. No horizonte "liberal", o objetivo último é maximizar o próprio interesse corporativo, subordinando coisas e pessoas, reduzidas a simples fatores de produção, ao imperativo da acumulação ilimitada de bens materiais numa contextualização em que o capital é o sujeito de todo o processo e por isso toda a produção é voltada apenas para a geração de lucros, o que desemboca numa espécie de equivalência de todos os bens, materiais 
e espirituais, sob a medida comum do dinheiro no seio do processo universal de mercantilização ${ }^{19}$.

$\mathrm{Na}$ perspectiva alternativa, isto é, no horizonte de uma economia orientada na construção histórica do ser racional e livre, todo o processo deve ocorrer não só tendo o desenvolvimento humano integral como objetivo, o que significa em primeiro lugar investir na melhoria das condições de vida das pessoas, mas igualmente de tal modo que os laços com os outros seres vivos e os demais seres da natureza sejam conservados, ou seja, que eles não sejam destruídos sem necessidade, antes se procure preservar as fontes de energia, o ar, a água potável e todos os fatores indispensáveis ao equilíbrio ambiental, e que os seres humanos e sua força de trabalho não sejam separados dos meios de produzir, dos outros seres humanos e da natureza nem reduzidos em seu ser a simples consumidores.

O que está em jogo é que, na configuração de uma nova sociabilidade, a economia deve estar a serviço da satisfação das necessidades reais das pessoas na busca de efetivação de relações integralmente humanas. Trata-se de gestão coletiva dos meios de produção por produtores livremente associados, ou seja, de uma economia sob controle social que tem na solidariedade e na cooperação seus valores éticos fundamentais. É uma economia que, como diz M. Arruda (2000, p. 164), "estriba as relações entre os sujeitos, nos valores da cooperação, da partilha, da reciprocidade, da complementariedade e da solidariedade".

Muda-se aqui o próprio significado que tem a economia nas sociedades marcadas pela competição: ela não constitui mais o objetivo central da vida humana, mas é um instrumento fundamental destinado a garantir adequadamente a reprodução material de todos, das gerações atuais e futuras. É importante acentuar que não se trata de eliminar nem o Mercado, nem o Estado, mas antes de repensá-los enquanto maneiras de relações sociais. A questão fundamental aqui é a da reconfiguração do mercado e do Estado através do controle dos cidadãos, o que significa dizer que eles se fazem, através de novas instituições, sujeitos da política e da economia. Dessa forma, mercado e Estado assumem uma nova configuração quando se tornam instrumentos do desenvolvimento humano numa estratégia participativa e igualitária de forma que se pode garantir a participação de todos na gestão dos bens produtivos. Todo esse empenho objetiva recriar o mercado sob o controle da sociedade e de um Estado entendido como regulador e fiscalizador do interesse comum subordinado à supervisão e às decisões da sociedade democraticamente organizada em todas as suas

\footnotetext{
19 A respeito de uma crítica a partir da posição aqui esboçada ao modelo liberal e ao modelo coletivista de organização da economia, cf. Oliveira (2010, p. 388 et seq).
} 
instâncias. Isso implica que o mercado se submeta às prioridades do desenvolvimento humano estabelecidas pelas diferentes instâncias de uma democracia deliberativa.

Projetar e transformar sua própria realidade individual e social, como algo específico de um ser inteligente e livre, significa na economia que os produtores associados possam reger conscientemente seu relacionamento com a natureza, ou seja, o planejamento, a produção e a repartição dos bens e submeter todo o processo a um controle social na ótica de uma responsabilidade socioecológica. "Em contraposição, portanto, à sociabilidade capitalista, na qual a associação é mediada pelas coisas, aqui a socialização é orientada na interação" (OLIVEIRA, 2015, p. 278). Dessa forma, o mercado deixa de ser um mecanismo inconsciente de regulação da vida humana de acordo com uma lógica estrutural autônoma e se transforma numa estrutura de relações entre agentes sociais conscientes e que tem seu espaço limitado a partir da referência aos interesses públicos. $O$ grande mérito desse tipo de configuração da vida social está no fato de que, assim, os seres humanos abrem o espaço de efetivação de suas potencialidades essenciais enquanto se fazem de fato sujeitos da vida social, o que significa dizer que nessa configuração da vida coletiva a sociedade civil se torna o elemento central e isso implica que o comunitário e o social se façam o eixo estruturador da vida coletiva das sociedades e da comunidade mundial.

Essa ética e seu fundamento metafísico desembocam num questionamento radical dos fins estabelecidos para a vida humana pela cultura moderna: a vida humana é centrada no desejo e na acumulação de bens por se pressupor um apetite ilimitado de consumir, o que leva a pôr no consumo de bens materiais o sentido da existência humana. Quando a própria atividade econômica se transforma em meio enquanto fundamento material do desenvolvimento, então ela precisa ser radicalmente repensada para eliminar toda produção do supérfluo e do excessivo, e isso abrirá um novo horizonte emancipatório para a humanidade. Para Diefenbacher (2001, p. 59), isso exigirá uma vinculação entre o "princípio da justiça" e o "princípio da sustentabilidade".

O princípio da diferença de Rawls reza que as desigualdades sociais e econômicas só podem ser aceitas se proporcionarem o maior benefício aos membros menos favorecidos da sociedade. Esse princípio pode e deve ser alargado na medida em que se considera também a participação no meio ambiente, e com isto no potencial de desenvolvimento dentro dos "limites do crescimento". Nessa perspectiva, o grau de justiça de uma sociedade depende de como ela regra o acesso aos recursos renováveis e não renováveis e de como ela permite à sua população a participação no direito de eliminar os elementos ameaçadores da vida de toda e 
qualquer espécie. Compete, então, ao Estado garantir aos indivíduos as liberdades e os direitos fundamentais. Nessa perspectiva os direitos têm primazia frente aos bens (KESSELRING, 2003, p. 193). Numa palavra, essa ética exige repensar os valores e os estilos de vida de nossa civilização técnico-científica.

\section{REFERÊNCIAS}

ARAÚJO, C. Nozick e o Estado. In: OLIVEIRA M. A. de; AGUIAR O. A.; SILVA SAHD L. F. N. de Andrade (org.). Filosofia política contemporânea. Petrópolis: Vozes, 2003, p. 272286.

ARISTÓTELES. De anima: livros I, II e III. São Paulo: Editora 34, 2012.

ARRUDA, M. Globalização e desenvolvimento comunitário autogestionário. In: ARRUDA

M.; BOFF, L. Globalização: desafios socioeconômicos éticos e educativos, 2000. p. 164.

ARRUDA, M.; BOFF, L. Globalização: desafios socioeconômicos éticos e educativos. 2. ed. Petrópolis: Vozes, 2000.

BRANQUINHO J. M. B. V. Problemas de metafísica logicamente disciplinada. Lisboa (mimeo), 2002.

BRAUDEL, F. Civilização material, economia e capitalismo: os jogos das trocas. São Paulo: Martins Fontes, 1996.

BROWN, W. Undoing the demos: neoliberalism's stealth revolution New York: Zone books, 2015.

CATATHARINO, A. Liberalismo. In: BARRETO, P. de; CULlETON, A. (org.). Dicionário de Filosofia Política Porto Alegre: Editora Unisinos, 2010.

CORTINA, A. Cidadãos do mundo: para uma teoria da cidadania. São Paulo: Loyola, 2005.

DARDOT, P.; LAVAL, Ch. A nova razão do mundo: ensaio sobre a sociedade neoliberal. São Paulo: Boitempo, 2016.

DIEFENBACHER, H. Gerechtigkeit und Nachhaltigkeit. Zum Verhältnis von Ethik und Ökonomie. Darmstadt: WBG, 2001.

FLICKINGER, H-G. Em nome da liberdade: elementos da crítica ao liberalismo contemporâneo. Porto Alegre: Edipucrs, 2003.

FRANK, M. Selbstbewusstsein und Selbsterkenntnis. Essays zur analytischen Philosophie der Subjektivität. Stuttgart: Reclam, 1991.

FRIEDMAN, M. Capitalism and freedom. Chicago: University of Chicago Press, 1961. 
HAYEK, F. A. von. The constitution of liberty. Chicago: University of Chicago Press, 1960.

HAYEK, F. A. von. The road to serfdom. Chicago: University of Chicago Press, 2007.

HEGEL, G. W. Grundlinien der philosophie des rechts. Hamburg: Felix-Meiner Verlag, 1955.

HEINTEL, E. Grundri $\beta$ der Dialektik, Band I: Zwischen Wissenschaftstheorie und Theologie. Darmstadt: Wissenschaftliche Buchgesellschaft, 1984.

HÖSLE, V. Die Philosophie und die Wissenschaften. München, 1999.

HÖSLE, V. Moral und Politik. Grundlagen einer Politischen Ethik für das 21:

Jahrhundert. München: Beck, 1997.

HÖSLE, V. Philosophie der ökologischen Krise: Moskauer Vorträge. München: Beck, 1991.

INWAGEN, P. v. How to think about the problem of free will. In: INWAGEN, P. v. Ethics, New York: Springer, 2008. p. 327-341.

JONAS, H. Organismus und Freiheit. Göttingen, 1973.

JONAS, H. Philosophische Untersuchungen und metaphysische Vermutungen. Frankfurt am Main/Leipzig: Insel Verlag, 1992.

KERSTING, W. Liberdade e liberalismo. Porto Alegre: Edipucrs, 2005.

KESSELRING, Th. Ethik der Entwicklungspolitik. München: Beck, 2003.

KEYNES, J. M. Teoria geral do emprego, do juro e da moeda. São Paulo: Atlas, 1992.

KRINGS, H. Freiheit. In: KRINGS H.;BAUMGARTNER H.M.;WILD Chr.(org.).

Handbuch philosophischer Grundbegriffe. v. 2, München: Kösel Verlag, 1973.

KRIPKE, S. Naming and necessity Cambridge, Mass: Harvard University Press, 1980.

KRIPKE, S. Identity and necessity. In: LOUX M. J. (org.). Metaphysics: contemporary readings. London/New York: Routledge, 2001, p. 218-247.

KUTSCHERA, F. v. Die Teile der Philosophie und das Ganze. Berlin/New York, de Gruyter, 1998.

LIMA VAZ , H. Claudio de. Ética e direito. São Paulo: Loyola, 2002.

MACPHERSON, C. B. A teoria política individualismo possessivo de Hobbes a Locke. Rio de Janeiro: Paz e Terra, 1979. 
MILL, S. De la liberte. Paris: Gallimard, 1990.

MISES, L. von. The anti-capitalist mentality. Auburn: Ludwig von Mises Institute, 2008.

NAGEL, Th. Wie ist es, eine Fledermaus zu sein? In: BIERI, P. (org.). Analytische

Philosophie des Geistes. Königstein/Ts.: Hain, 1981.

NOZICK, R. Anarchy, state and utopia. New York: Basic Books, 1974.

OLIVEIRA, M. A. de Antropologia filosófica contemporânea: subjetividade e inversão teórica. São Paulo: Paulus, 2012.

OLIVEIRA, M. A. de. Desafios éticos da globalização. 3. ed. São Paulo: Paulinas, 2008.

OLIVEIRA, M. A. de. Ética, direito e democracia. São Paulo: Paulus, 2010.

OLIVEIRA, M. A. de. Ética e economia. São Paulo: Ática, 1995a.

OLIVEIRA, M. A. de. Ética e práxis histórica. São Paulo: Ática. 1995 b.

OLIVEIRA M. A. de. A ontologia em debate no pensamento contemporâneo. São Paulo: Paulus, 2014.

OLIVEIRA, M. A. de. Ética e sociabilidade. 5. ed. São Paulo: Loyola, 2015.

OLIVEIRA, M. A. de. Tópicos sobre dialética. Porto Alegre: Edipucrs, 1996.

OLIVEIRA, M. A. de; AGUIAR, O. A.; SILVA SAHD L. F. N. de Andrade (org.). Filosofia política contemporânea. Petrópolis: Vozes, 2003

PIVA, E. A. A questão do sujeito em Paul Ricoeur. Síntese, Belo Horizonte, v. 26, n. 85, p. 205-237, 1999.

PILZ, F. Die Soziale Markwirschaft. Konzeption, Wirklichkeit, Perspektiven. München: Bayerische Landeszentrale für polistische Bildungsarbeit, 1974.

PLANTING, A. The nature of necessity. Oxford: University Press, 1974.

PUNTEL, L. B. Estrutura e ser: um quadro referencial teórico para uma filosofia sistemática. São Leopoldo: Ed. Unisinos, 2008.

RICOEUR, P. O si-mesmo como um outro. Campinas: Papirus, 1991.

RICOEUR, P. Percurso do reconhecimento. São Paulo: Loyola, 2006.

SANDEL, M. J. Justiça: o que é fazer a coisa certa. Rio de Janeiro: Civilização Brasileira, 2012.

SAVIDAN, P. Repensar a igualdade de oportunidades. São Paulo: Paulus, 2010. 
SEN, A. Desenvolvimento como liberdade. São Paulo: Companhia das Letras, 2000.

STRAWSON, P. Einzelding und logisches Subjekt (Individuals). Ein Beitrag zur deskriptiven Metaphysik. Stuttgart: Reclam, 1972.

STIGLITZ, J. Rewriting the rules of american economy. New York: Roosevelt Institute, 2015.

SUNG, M. J. Idolatria do dinheiro e direitos humanos: uma crítica teológica do novo mito do capitalismo. São Paulo: Paulus, 2018.

TAYLOR, Ch. Sources of the self: the making of modern identity. Cambridge, Mass:

Harvard University Press, 1989.

VIANA, W. C. A Metafísica da pessoa: o problema da identidade pessoal. São Paulo: Ideias \& Letras, 2019.

VIANA, W. C. Hans Jonas e a filosofia da mente. São Paulo: Paulus, 2016. 